\title{
Beyond Binary Opposition: Reinterpretation of Mr. Pontellier in the Awakening
}

\author{
ZHANG Yan-hua \\ Weifang Medical College, Weifang City, China
}

\begin{abstract}
The American writer Kate Chopin's masterpiece, The Awakening published in the late 19th century is one of the classics in female literature. The heroine Edna having the courage to pursue self-reliance and express her self-awareness, is regarded as a "new woman”, while the comments on her husband, Mr. Pontellier are quite negative-He regards Edna as a private property and a sexual tool, leading to her awakening and suicide. In this paper, the author reinterprets Mr. Pontellier with the method of close reading in new criticism, deeming that it is the binary opposition in thinking that leads to the misreading. Mr. Pontellier was just a follower of the tradition and custom. The objective evaluation and reinterpretation to him can help students to develop the habit of critical thinking and the courage to pursue truth is case they form a simple thinking mode of the binary opposition.
\end{abstract}

Keywords: the Awakening, Pontellier, Edna, binary opposition thinking

\section{Introduction}

The American writer Kate Chopin's masterpiece, The Awakening, published in the late 19th century, is one of the classics in female literature. In the novel, Kate Chopin describes the heroine Edna's developing self-awareness from awakening, to pursuit, then to suffocation at last in a historically patriarcle society. Not content with a boring marriage, Edna's love is awakened by Robert. Being aware that their relationship will violate tradition and customs, Robert chooses to escape time and again. In great desperation, Edna throws herself into the sea with mixed feelings.

The Awakening is a popular feminist novel in foreign literature in colleges in China. Readers have mixed reflections and comments about Mr. Pontellier and his wife Edna. Edna is regarded as a "new woman", having the courage to pursue self-reliance and to express her self-awareness, while the comments on her husband, Mr. Pontellier are quite negative- - He regards Edna as a private property and a sexual convenience, which leads to her awakening and suicide. Is that true? In this paper, the author reinterprets Mr. Pontellier with the method of close reading in new criticism.

\section{Mr. Pontellier in the Text of the Awakening}

Mr. Pontellier is mentioned in several plots in the Awakening. He was a man of 40 in New Orleans, "wearing eye-glasses, his hair is brown and straight, parted on one side. His beard is neatly and closely trimmed" (Chopin, 2007, p. 1). He did not forget reading newspapers even though he was spending a holiday at the seaside, "He was already acquainted with the market reports, and he glanced restlessly over the editorials 
and bits of news which he had not had time to read before quitting New Orleans the day before”. In a few words, Mr. Pontellier's image is displayed in front of readers: A businessman who is well-educated, capable and concerned about news.

In the eyes of his two young children, Mr. Pontellier was a conscientious father. Before going to bed, he would enter their bedroom to determine whether they slept well. When he was away from home and on business, he would buy the children various delicious foods, and Edna was quite used to receiving a box-full of "the finest of fruits, pates, a rare bottle or two, delicious syrups, and bonbons in abundance" (Chopin, 2007, p. 10); When he came back home, he would bring some colored sheets of the comic papers accumulated. At that time, some peers of the two little Pontellier boys would gather around them, and they "permit them to have a look", this "making their authority felt" (Chopin, 2007, p. 33). Obviously, not all the fathers could behave like Mr. Pontellier, who had a good understanding of children and tried to satisfy children's preferences. It was not surprising that the boys were reluctant when he left home on business, "tumbling about, clinging to his legs, imploring that numerous things be brought back to them” (Chopin, 2007, p. 10).

For Edna, his wife, 12 years younger than himself, Mr. Pontellier showed consideration for her as well. When Edna felt scared when she began to learn swimming, he comforted her: "You are not so very far, my dear, I was watching you” (Chopin, 2007, p. 41). Not content with her boring marriage life, Edna didn’t care much about others' feelings, her abrupt departure might put an end to the pleasure of her neighbors. Sometimes her unique character and conducts made them feel down. When hearing their neighbors' compliaints, Mr. Pontellier just explained: "I know she is, sometimes, not often" (Chopin, 2007, p. 41).

Leonce Pontellier provided a luxurious life for his family. He was fond of creating a comfortable environment, he decorated a very charming home on Esplanade Street (one of the best residential area) in New Orleans. "Within doors the appointments were perfect after the conventional type. The softest carpets and rugs covered the floors; rich and tasteful draperies hung at doors and windows" (Chopin, 2007, p. 78). When Edna told him to save the money, he said: "the way to become rich is to make money, my dear Edna, not to save it" (Chopin, 2007, p. 78). He tried to be a good provider as a good man should be at that time. As a result, the majority of the local women were all envious of Edna, "whose husbands were less generous than Mr. Pontellier” (Chopin, 2007, p. 73).

One situation, which is frequently cited by critics lies in Chapter Eleven. Mr. Pontellier came back home at nearly two at night, finding that Edna was still in the courtyard with no intent to sleep. Mr. Pontellier made the bed and asked her to enter the house, saying it was too late and cold, and outside there were some mosquitoes which would devour her. When Edna refused, Mr. Pontellier blurted out: "What folly is this? Why don't you come in” (Chopin, 2007, p. 45). When Edna refused again, he couldn’t help saying, "This is more than folly. I can't permit you to stay out there all night. You must come in the house instantly" (Chopin, 2007, p. 46). This was one of the most serious disagreements between them in the novel. "If I mean to stay out here, I don't wish to go in, and I don't intend to. Don’t speak to me like that again; I shall not answer you”. Faced with Edna's refusal and resistance, Mr. Pontellier just opened a bottle of wine, and handed it to his wife, but she gave no responses at all. Helplessly, Mr. Pontellier had to sit into the corridor, smoking one cigarette after another. Until it was nearly dawn, Edna got up from the hammock, asking “Are you coming in?” Mr. Pontellier's answer was "Yes, dear, Just as soon as I have finished my cigar” (Chopin, 2007, p. 47). In the patriarchal society, it was not difficult to find how generous and tolerant Mr. Pontellier was. Unfortunately, what we read in other critics is only his power and desire for sex. 
When spending a vacation in Grand Island, Edna was deeply attracted by Robert's romance and passion. Due to the pressure of tradition and custom, Robert escaped and left her for Mexico. Edna was in a very bad mood,

Robert's going had in some way taken the brightness, the color, the meaning out of everything. The conditions of her life are in no way changed, but her whole existence is dulled, like a faded garment which seems to be no longer worth wearing... She sought him everywhere—in others whom she induced to talk about him. (Chopin, 2007, p. 67)

Everything about Robert attracted her repetition and attention. Even when Mr. Pontellier came home from his business, he says to her: "How do you get on without him (Robert), Edna?” (Chopin, 2007, p. 68). She admitted life was very dull without him. When Mr. Pontellier mentioned he had seen Robert in the city, Edna asked him "a dozen questions or more" about Robert. He answered all the questions one by one, saying he thought Robert was promising. When seeing Edna was not well, he told her to take good care of herself. In addition, he himself went personally to consult a doctor (Chopin, 2007, p. 95). Mr. Pontellier, of course could perceive Edna's favorable impression on Robert, but he was never jealous. Instead, he trusted his wife.

Edna didn't attend to her sister's wedding without giving any obvious excuses. Mr. Pontellier bought wedding gifts, telling Edna's father "he would endeavor by every means which money and love could devise to compensate for Edna's incomprehensible action”. Her father reproached his daughter for "her lack of filial kindness and respect, her want of sisterly affection and womanly consideration” (Chopin, 2007, p. 104), He even persuaded his son-in-law, "You are too lenient, too lenient by far. Authority, coercion are what is needed. Put your foot down good and hard; the only way to manage a wife. Take my word for it” (Chopin, 2007, p. 104). Edna's father forgot it was his cruelty and tyranny leading to the death of his wife.

In a patriarchal society, not all men could behave like Mr. Pontellier. Woolf (1993) ever mentioned British women's situation in about 1470, according to Professor Trevelyan's History of English,

Wife-beating, was a recognized right of man, and was practiced without shame by high as well as low... In the time of the Stuarts, it was still the exception for women of the upper and middle class to choose their own husbands, and when the husband had been assigned, he was lord and master, so far at least as law and custom could make him.

The so-called lords or masters did not appear only in Britain, of course. Edna's father was one of them. Compared with them, Mr. Pontellier had lots of good qualities. In the eyes of the neighborhood, Mr. Pontellier was the best husband in the world. Mr. Pontellier "was a great favorite, and ladies, men, children, even nurses, were always on hand to say goodbye to him” (Chopin, 2007, p. 10). Even Edna was forced to admit that she knew of none better.

\section{Why a Different Mr. Pontellier Appeared in Comments}

In the novel, Mr. Pontellier is compassionate and generous with a good reputation in the eyes of the neighbors and the family members. But in comments, both in China and abroad, why we read a different Mr. Pontellier?

In the novel, Edna is described as a property twice. In Chapter One, this is also frequently cited in comments: After Edna finished swimming with Robert, Mr. Pontellier exclaimed, "What folly! To bathe at such an hour in such heat!” He added: "You are burnt beyond recognition, looking at his wife as one looks at a valuable piece of personal property which has suffered some damage” (Chopin, 2007, p. 3). Another reference is in Chapter thirty-six, when Robert said he left for Mexico because Edna was not free, she was Leonce 
Pontellier's wife, Edna told him, “I am no longer one of Mr. Pontellier’s possessions to dispose of or not. I give myself where I choose” (Chopin, 2007, p. 156).

It is the metaphor of property in this novel as well as in other literature works that makes readers draw the conclusion, Mr. Pontllier regards Edna as a property. What's more, the leading reason is from readers' binary opposition: either white or black, either this or that, there is no intermediate regions between them in thinking. In order to emphasize the positive significance of Edna's awakening of self-awareness in the patriarchal society, her husband, Mr. Pontellier is regarded as the opposite: it is he who regards his wife as property, a sexual tool, his tyranny and subjective assertion leads to Edna's awakening and her affairs with Robert, which leads to her suicide in the sea at the end.

Compared with the social background and text in the novel itself, such an interpretation is rather simple and lop-sided. At the end of the 19th century in the United States of America, despite it was a time of changes, the majority of women's roles were still tied to the home. A woman was defined as "someone's daugher, someone’s wife, someone's mother, someone’s mistress" (Martin, 2007, p. 14), who had no rights to choose her own life. Edna's behavior was seen as rebellious, which offended the tradition and the custom of the time; this was why "the Awakening" was forbidden shortly after it was published.

In the novel, Edna's father was arbitrary. Her mother died early when she was very young, so even as a child, she had lived her own life within herself. "At a very early period she had apprehended instinctively the dual life - that outward existence which conforms, the inward life which questions” (Chopin, 2007, p. 20).

After she married Mr. Pontellier, she lived a superior life with maids looking after the children and cooking at home, She didn't have to take on the heavy housework as other women did at that time. On weekends, she could even accompany her husband to enjoy concerts. However, she had to conform to a woman's role: stay at home to manage domestic affairs. She felt "it did not seem worthwhile to be glad or sorry, to be alive or dead"; "when life appeared to her like a grotesque pandemonium and humanity like worms struggling blindly toward inevitable annihilation” (Chopin, 2007, p. 85).

Influenced by Adele, Reisz, and Robert, Edna's sense of self-awareness was gradually sprouting. She had not been associating with anybody else. She had abandoned her Tuesdays' duties at home and ignored all her acquaintances. She no longer tried to restrain herself in the church, or to restrain herself around the home. She was learning to perceive the world with her own eyes and with her own heart: painting, swimming, horse racing, trying to be financially independent. However, any behavior that contradicted the roles of a wife, a mother and a daughter was deemed to discard because it didn't conform to the gender roles of women, these actions clearly violated the social customs, posing a threat to her husband's social status and dignity.

Edna was not a mother-woman, who were "fluttering about with extended, protecting wings when any harm, real or imaginary, threatened their precious brood” (Chopin, 2007, p. 11). Mr. Pontellier was confined by tradition and custom. Therefore, he couldn't understand Edna's pursuit, even feeling shocked. But he just advised her, "Don't let the family go to the devil. There's Madame Ratignolle; because she keeps up her music, she doesn't let everything else go to chaos. And she's more of a musician than you are a painter” (Chopin, 2007, p. 83). He believed that, as a man, he should work hard outside to earn enough money to support the family. In the viewpoint of Mr. Pontellier, Edna, as a mother, should look after their children; sometimes he blamed Edna due to her lack of concern for the children. He didn't bring Edna romance or passion, but he was not vulgar or overbearing. In addition, he didn’t limit Edna's freedom or pursuits. As a matter of fact, he had many admirable qualities such as consideration, tolerance and generosity. His name "Pontellier" (Pontellier means "bridge" in 
French), functions as a metaphor that he is evolving from men's despotism like Edna's father, to a more modern conception of a gentleman's role as a husband.

When alone, Edna often remembered "his many acts of consideration and his repeated expressions of an ardent attachment” (Chopin, 2007, p. 105). But they had no common interests or hobbies. In her heart, her husband was not her true love; the holy marriage was regarded as an "accident", even though, she dared not divorce.

When the Awakening was published, marriage in New Orleans was based on the Napoleonic Code, which defined a wife and everything she possessed, including her clothes, as her husband's property. Divorce was an infrequent and scandalous event, particularly in Lousisiana, which was a Catholic state. In 1890, there were only 29 divorces per 100,000 population, and until 1888 the custody of children was automatically given to the husband. (Martin, 2007, p. 17)

After Robert returned from Mexico, he escaped again under the pressure. In great desperation, Edna walked into the sea, just like the bird at the end of the novel, "with a broken wing, beating the air above, reeling, fluttering, circling disabled down, down to the water” (Chopin, 2007, p. 167).

Undoubtedly, Edna was a victim, but the person who deprived her freedom or pursuits was not Mr. Pontellier, who was just a follower of the tradition and custom. The major cause was the powerful patriarchal society they lived in. People who loved each other could not get together; the marriage without love had to be maintained under the pressure of patriarchy. To some extent, Edna, Robert, and Mr. Pontellier were all victims of the rigid social system.

However, when she struggled to break the bondage of the society of women, completely and entirely forgetting her responsibilities in family or society, she chose an extreme alternative. Just blindly criticizing her husband, Mr. Pontellier, ignoring all his virtues, such an interpretation is clearly lop-sided, narrow and unfair. The 2012 Nobel laureate Mo Yan ever said (2013) ${ }^{1}$, “No matter how good a person is, he or she must have his or her own shortcomings. No matter how great a hero is, he must have his own weakness". The human nature is complicated, the author, Kate Chopin did not employ the simple binary opposition thinking mode when describing Mr. Pontellier in a neutral way, which reflected her consideration on human nature and her superb writing skills.

In the patriarchal society in the 19th century, Edna, with her courage to challenge the traditional constraints on women, had a positive significance undoubtedly. Her words revealed her persistence, "I would give up the unessential; I would give my money, I would give my life for my children; but I wouldn't give myself” (Chopin, 2007, p. 69). "Perhaps it is better to wake up after all, even to suffer, rather than to remain a dupe to illusions all one's life” (Chopin, 2007, p. 162). In a substantial family, Edna realized "her position in the universe as human being, and to recognize her relations as an individual to the world within and about her" (Chopin, 2007, p. 19). Obviously, Edna's awakening has a practical significance, reflecting women's pursuit of freedom and spiritual value. Through this, the author managed to appeal directly to the society, substances are not the only thing in life, and women also need to have more rights and freedom, the essence!

\section{Conclusion}

As one of the most intensely read works in feminist canon, The Awakening has a textual ambiguity and a variety of interpretations. The world is colorful, there exist a lot of intermediate colors between black and white.

${ }^{1}$ Mo Yan’s Speech in Shandong University. Retrieved from http://www.sd.xinhuanet.com/news/2013-04/28. 
There is no exception in literary works. Between the binary opposites, such as, this and that, good and evil, beautiful and ugly, there are many intermediate states, which is consistent with the literature of the original state. The binary opposites thinking tend to confine students' thinking, making them see only leaves instead of a forest, not perceiving the essence of a problem.

The objective evaluation and reinterpretation to Mr. Pontellier can help students to develop the habit of critical thinking and the courage to pursue truth, avoiding them to develop a simple mode of the binary opposition. Otherwise, when they graduate and work in the society, they will not be able to meet the challenges in the new century in the world.

\section{References}

Chopin, K. (2007). The Awakening. Shanghai: Shanghai Foreign Language Education Press.

Culley, K. (1976). Edna Pontellier: A solitary soul. In M. Culley(Ed.), The awakening. New York: Nortion.

Martin, W. (2007). New essays on the awakening. Beijing: Peking University Press.

Woolf, V. (1993). A room of one's own. Harmondsworth, Middlessex: Penguin. 